\title{
HistoricAl BACKGROUND OF UMBILICAL STEM CELL CULTURE
}

Sylwia Borys-Wójcik ${ }^{1}$, Małgorzata Józkowiak², Katarzyna Stefańska ${ }^{3}$, Sandra Knap³, Wojciech Pieńkowski ${ }^{4}$, Paweł Gutaj ${ }^{5}$, Małgorzata Bruska ${ }^{1,}$ Bartosz Kempisty ${ }^{1,3,6}$

\begin{abstract}
Umbilical cord is a waste material, and therefore does not raise ethical concerns related to its use for research and medicine. Stem cells from umbilical cord have a significant advantage over cells from other sources. First, the umbilical cord is an infinite source of stem cells, because it can be taken theoretically during each delivery. Secondly, acquisition of umbilical cord is a non-invasive, safe procedure for mother and child. Thirdly, the transplantation of umbilical cord stem cells is associated with a lower risk of infection and a less-frequent "graft versus host" reaction. In this work, the authors present a historical background of research on the cell from its discovery to modern times characterized by highly advanced methods of obtaining stem cells from umbilical cord and from other sources.
\end{abstract}

Running title: History of umbilical stem cell culture

Keywords: umbilical stem cells, history of umbilical stem cells

\footnotetext{
${ }^{1}$ Department of Anatomy, Poznan University of Medical Sciences, Poznan, Poland

${ }^{2}$ Department of Toxicology, Poznan University of Medical Sciences, Poznan, Poland

${ }^{3}$ Department of Histology and Embryology, Poznan University of Medical Sciences, Poznan, Poland

${ }^{4}$ Division of Perinatology and Women's Diseases, Poznan University of Medical Sciences, Poznan, Poland

${ }^{5}$ Department of Reproduction, Poznan University of Medical Sciences, Poznan, Poland

${ }^{6}$ Department of Obstetrics and Gynecology, University Hospital and Masaryk University, Brno, Czech Republic

* Correspondence: mbruska@ump.edu.pl

Full list of author information is available at the end of article
} 


\section{Introduction}

The construction of living organisms has been the subject of people's interests since antiquity. In the available literature one can find information that in the years 500-428 BC, Greek philosophers were making various theories about the structure of organisms. Anaxagoras from Kladzom - an ancient atomist claimed that reality is built from matter consisting of immutable and infinite "seeds" and from self-governing reason, which was supposed to set in motion and cause connection and disconnection of elements [1].

\section{The Seventeenth to Nineteenth Centuries}

In 1665, Robert Hooke, an English naturalist, observed the existence of compartments in tissues, describing the cell - the smallest functional and structural unit of living organisms capable of carrying out all life processes [2]. In 1839, two German scholars: zoologist - Theodor Schwann and botanist - Matthias Jacob Schleiden put forward a cellular theory that all living organisms are made of cells. The above theory was created in two stages. In 1838 Mattihas Jacob Schlieden stated that all plant organisms were made of cells, and a year later Theodor Schwann extended the application of the German botanist by stating the existence of an animal cell $[3,4]$. The essence of in vitro cell culture is to maintain their vital functions outside the living organism [5]. Interest in the culture of cells, tissues and organs outside the body became the subject of interest of scientists shortly after the discovery of their existence. Carl Friedrich Wilhelm Ludwig German physician, physiologist, professor of physiology and topographic anatomy in 1856 developed techniques of organ perfusion after removing them from the body. The essence of the experiment was to pump blood through organs taken from the body. Three years later - in 1859, a French neurologist Edmé Félix Alfred Vulpian isolated fragments of tadpole tail and attempted to breed them in water. Cells isolated by Edmé Félix Alfred Vulpian, despite their survival in water, did not reproduce. However, the experience of the French neurologist showed that cell survival in vitro is possible [1]. Twenty-one years later, the English clinician Sidney Ringer conducted research on the work of the cardiac muscle of animals placed in $0.75 \%$ saline and the effect of additional substances added to it (blood, albumin, potassium). The British researcher proved that it is possible to survive the organs for a long time, provided they are kept in a sodium chloride solution with small amounts of potassium. In 1885, the German embryologist Wilhelm Roux proved that it is possible to keep the nerve plate obtained from the chicken embryo in a heated saline solution. Unfortunately, all attempts carried out resulted in a bacterial or fungal infection [6].

\section{The Twentieth Century}

In 1903, Justin Marrie Jolly, a French hematologist and histologist, attempted to breed nucleated red blood cells. He was also referencing the work of the German botanist Gotlieb Haberland, who thanks to the breeding medium he developed, increased the size of the cultured cells, but did not obtain their multiplication. The blood cells cultured by Justin Jolly divided for the first 15 days, after which they gradually lost ability to cell divisions until total arrest few months after the start of cultivation [7]. In 1906, two American scientists, Charles William Beebe - zoologist and oceanographer, and oceanographer James Ewing, made a successful attempt to in vitro maintain a dog lymphosarcoma cells. The breakthrough moment in in vitro cell culture is considered to have occurred in 1907 [8]. In this year, Ross Granville Harrison, an American biologist and anatomist, achieved success in in vitro cultivation of diverse nerve cells of the radial nerve of amphibian embryos [9]. Harrison placed fragments of the nervous tissue of the frog's embryo in a drop of congealed lymph. This experiment showed that axons of nerve cells are formed from protrusions that grow out of the body of nerve cells. Harrison also observed the movement of the cytoplasm from the cell body to the protrusions [10]. During the first observations, Harrison used frog cells, as they were not hard to maintain in cells cultures. The frog is a cold-blooded animal, so its cells do not require incubation under constant conditions. In addition, tissue regeneration is more effective in lower vertebrates. Therefore, Harrison supposed that the experience would have a greater chance of success than with the use of mammalian cells [11]. Ross Harrison is considered the creator of the methods used in cell culture [1]. The American also developed a cell culture technique "in a hanging drop". Then, thanks to cooperation with Montrose Thomas Burrows, a surgeon and pathologist, he succeeded in developing a cell culture technique in a drop of clotted plasma placed on a microscope slide. Montorse Thomas Burrows began his collaboration with Harrison thanks to Alexis Carrel, a French surgeon, Nobel Prize winner in physiology and medicine in 1912. Burrows, as an assistant to Alexis Carrel, was sent by him to Harrison's laboratory to learn about the cell culture techniques. Carell's goal was to adopt Harrison's techniques for research on warm-blooded animals. Montorse Thomas Burrows has been very successful during his cooperation with Harisson. In 1910 he successfully established a tissue culture of embryonic chicken cells [1]. After returning, Thomas Burrows and Alexis Carrel introduced a number of improvements to Harrison's culture techniques. These improvements included, among other things, the use of a lymph instead of blood plasma and the addition of an extract from the em- 
bryo to the nutrient medium used for tissue culture. Improvements made by scientists have contributed to, inter alia, improving the growth of tissue cultures. In the years 1911-1912 Carrel, in cooperation with Burrows, successfully maintained cellular explants from cats, dogs, rats or guinea pigs. Cancer cells became the subject of their further interest [1]. Alexis Carrel made a breakthrough in tissue culture introducing a number of recommendations for aseptic culture techniques. Carrel assumed that the collection of material and the establishment and maintenance of the culture should take place in accordance with the principles of antiseptics. The place of operation should be a sterile box and the tools used should be sterile. He also assumed the use of sterile media. Alexis Carrel also introduced the method of culture in a thrombus blood clot. He was also the originator of cell culture in a coagulum formed by mixing embryo extract of chicken embryos and plasma [12]. The experience of the French Nobel Prize winner showed that, thanks to the use of an embryonic extract and asepsis during cell cultures, it is possible to keep the cells out of the body for many years. Alexis Carrel, thanks to the regular and continuous passage of fibroblasts from the heart of the chicken to the fresh breeding medium, obtained a continuous culture. Carrela's cell culture was continued for the next thirty-four years by Albert H. Ebeling - using it to test germicides [13]. Carrela's close associate was also Charles Augustus Linbergh - an American airman who became famous for the first lonely passage between North America and Europe. Pilot was the originator and contractor of a large number of devices used by Carrela for tissue culture. Lidbergh constructed, among others, a press for crushing chicken embryos. Carrel also worked on the construction of instruments used in the research [14].

Another breakthrough in the subject of in vitro cell culture took place in 1916, when Francis Peyton Rous - American physician and pathologist, Nobel laureate in 1966 with Jones for the first time use of a proteolytic enzyme - trypsin. Tryspin was used to dissociate single cells from tissue fragments. After dissociation, the cells were placed in the culture medium, resulting in a suspension of viable cells. The idea of using trypsin to dissociate individual cells is practiced to this day [15].

The 1930s was the period of further development of scientific in vitro cell culture techniques. Professor Zygmunt Grudzinski of the Jagiellonian University is considered as the forerunner of tissue culture in Poland. Professor Grudzinski, as a Rockefeller Foundation scholarship holder, completed an internship in the laboratory of the student of Carrela - professor Maxirnov. The Pole had the opportunity to learn the methods of chicken embryo tissue culture in a hanging drop. In 1933, Alexis Carrel, in cooperation with cell biologist Georg Otto Gey, con- structed a device extremely helpful in conducting long-term cell culture - the so-called roller tube. From the late 1930s, the first reports on the therapeutic use of umbilical cord blood were also made. About ten years later, antibiotics began to be used in cell culture [12], and in 1948 the first synthetic cell culture medium was developer [1].

The discovery of the HeLa tumor cell line has been a specific revolution in in vitro research. The HeLa line was prepared by Elexis Carrel and George Gey. In 1951, tissues were removed from a patient diagnosed with cervical cancer and sent to the Tissue Culture Laboratory. Human umbilical cord blood was then used as a cell culture medium. By studying the tumor cells obtained from the tumor (HeLa line), Gey noticed that these cells are dividing continuously and do not die. During the previous studies, the cells died after a few days of culture as opposed to the newly discovered HeLa cells. Several studies have been carried out using HeLa cells and many scientific papers have been published on the findings [16].

More than a decade later, a Japanese scholar, Maruyama took effective attempts to harvest stem cells from the umbilical vein. Maruyama proposed obtaining stem cells by cannulation of the umbilical vein and by means of enzymatic activity of trypsin [17].

The seventies of the twentieth century were a time of increased attempts to obtain pluripotent cells. In 1981, mouse pluripotent embryonic stem cell lines with normal karyotype were successfully isolated from blastocysts [18]. Seven years later, in 1988, on the initiative of American doctors: Hana Broxmeyer and Joanna Krutzberg and prof. Eliane Gluckman at the Paris Clinic undertook the first trial in the history of umbilical cord blood cell transplantation [19]. Umbilical cord blood is a rich source of pluripotent cells that can be dedifferentiated into any type of cell in the human body. An umbilical cord blood of a newborn sister was given to the boy who was ill with Fanconi's anemia. A few days after the transplantation, blood cells derived from the donor cells were found in his bloodstream. The first allogeneic transplantation of frozen and banked umbilical cord blood was performed in 1993. A few years later, it was proved that the cord blood has enough stem cells to repopulate the recipient's marrow. Evidence has also been provided that there is less risk of allograft rejection compared to bone marrow transplantation [20]. The first cord blood stem cell transplant in Poland took place in 1994 to treat a boy suffering from acute myelogenous leukemia.

\section{The Twenty-First Century}

In 2001, more than one blood unit was transplanted in the USA. In Poland, a similar transplant was performed in a patient with refractory chemotherapy-resistant acute leukemia in 2003. In March 
2007, the first Polish transplant of banked cord blood was performed at the Children's Hematology Clinic in Wroclaw. The blood for transplant was collected in 2004 [21].

\section{Conclusion}

Stem cell transplants taken from the umbilical cord over the years gain a wider range of applications and the use of cells stored in banks contributes to saving or improving the quality of life of many patients. The data of Polish Stem Cell Bank show that, since 2011, more than 1194 umbilical cord stem cell transplants were conducted in Poland [22].

\section{Ethical approval}

The conducted research is not related to either human or animal use.

\section{Acknowledgements}

This publication and its results are an outcome of a cooperation between Poznan University of Medical Sciences (Poznań, Poland) and Polish Ministry of Science and Higher Education, with Institute of Advanced Sciences Sp. z o.o. (Poznań, Poland), as a part of the "Professional PhD" programme.

\section{Corresponding author}

Małgorzata Bruska, Department of Anatomy, Poznan University of Medical Sciences, 6 Święcickiego St., 60-781 Poznań, Poland Tel./ Fax: +48618546565, e-mail: mbruska@ump.edu.pl.

\section{Conflict of interest statement}

The authors declare they have no conflict of interest.

\section{References}

1. Olszewska-Słonina DM, Drewa TA. Cell culture, tissue engineering and regenerative medicine. Part I. Wiadomosci Lek Wars Pol. 1960;59:585-9.

2. Gest H. The remarkable vision of Robert Hooke (1635-1703): first observer of the microbial world. Perspect Biol Med. 2005;48:266-72; DOI:10.1353/pbm.2005.0053.

3. Vasil IK. A history of plant biotechnology: from the Cell Theory of Schleiden and Schwann to biotech crops. Plant Cell Rep. 2008;27:142340; DOI:10.1007/s00299-008-0571-4.

4. Sonig A, Gandhi V, Nanda A. From the cell of Schwann to schwannoma--a century's fruition. World Neurosurg. 2014;82:906-11; DOI:10.1016/j. wneu.2014.05.038.

5. Thorpe T. History of plant tissue culture. Methods Mol Biol Clifton NJ 2012;877:9-27; DOI:10.1007/978-1-61779-818-4_2.

6. Moore B. In Memory of Sidney Ringer [1835-1910]: Some account of the Fundamental Discoveries of the Great Pioneer of the Bio-Chemistry of Crystallo-colloids in Living Cells. Biochem J. 1911;5:i.b3-xix DOI:10.1042/bj005000i.

7. Laubry C. [Justin Jolly (1870-1953)]. Rev Hematol. 1953;8:230-4

8. Freshney R. Culture of Animal Cells: A Manual of Basic Technique and Specialized Applications, Sixth Edition. 2010;346 DOI:10.1002/9780470649367.

9. Harrison RG, Greenman MJ, Mall FP, Jackson CM. Observations of the living developing nerve fiber. Anat Rec. 1907;1:116-28; DOI:10.1002/ ar.1090010503.

10. Maienschein J. Ross Granville Harrison (1870-1959) and perspectives on regeneration. J Exp Zoolog B Mol Dev Evol. 2010;314:607-15 DOI:10.1002/jez.b.21368.

11. Gähwiler BH. Nerve cells in culture: the extraordinary discovery by Ross Granville Harrison. Brain Res Bull. 1999;50:343-4.

12. Carrel A. On the permanent life of tissues outside of the organism. J Exp Med. 1912;15:516-28; DOI:10.1084/jem.15.5.516.

13. Ebeling AH. The permanent life of connective tissue outside of the organism. J Exp Med. 1913;17:273-85; DOI:10.1084/jem.17.3.273.

14. Pai-Dhungat JV, Parikh F. Alexis Carrel (1873-1944). J Assoc Physicians India. 2015;63:94-5.

15. Kumar P, Murphy FA. Who is this man? Francis Peyton Rous. Emerg Infect Dis. 2013;19:661-3; DOI:10.3201/eid1904.130049.
16. Jones HW, McKusick VA, Harper PS, Wuu KD. George Otto Gey. (1899 1970). The HeLa cell and a reappraisal of its origin. Obstet Gynecol. 1971;38:945-9.

17. Jiménez N, Krouwer VJD, Post JA. A new, rapid and reproducible method to obtain high quality endothelium in vitro. Cytotechnology. 2013;65:114; DOI:10.1007/s10616-012-9459-9.

18. Evans MJ, Kaufman MH. Establishment in culture of pluripotential cells from mouse embryos. Nature. 1981;292:154-6.

19. Ballen KK, Gluckman E, Broxmeyer HE. Umbilical cord blood transplantation: the first 25 years and beyond. Blood. 2013;122:491-8; DOI:10.1182/blood-2013-02-453175.

20. Bielec B, Stojko R. Stem cells of umbilical blood cord - therapeutic use. Postepy Hig Med Doswiadczalnej Online. 2015;69:853-63.

21. Piskorska-Jasiulewicz MM, Witkowska-Zimny M. Perinatal sources of stem cells. Postepy Hig Med Doswiadczalnej Online. 2015;69:327-34; DOI:10.5604/17322693.1143052.

22. Macierzystych PBK. Lista przeszczepień PBKM - PBKM n.d. https:// www.pbkm.pl/o-komorkach-macierzystych/gdzie-wykorzystuje-sie-komorki-macierzyste/przeszczepienia-pbkm (accessed May 13, 2019). 